\title{
Managing forest genetic resources as a strategy to adapt forests to climate change: perceptions of European forest owners and managers
}

\author{
Barbara Vinceti $^{1}$ (D) $\cdot$ Mattia Manica ${ }^{2}$ (D) Nina Lauridsen ${ }^{1}$ (D) $\cdot$ Pieter Johannes Verkerk $^{3}$ (D) Marcus Lindner $^{4}$ (D) \\ Bruno Fady 5 (iD
}

Received: 21 May 2020 / Revised: 11 August 2020 / Accepted: 25 August 2020 / Published online: 2 September 2020

(c) The Author(s) 2020

\begin{abstract}
Managing genetic diversity is of key importance in fostering resilience of forest ecosystems to climate change. We carried out a survey reaching over 200 forest owners and managers from 15 European countries to understand their perceptions of the main threats to forest ecosystems, their knowledge of forest genetic resources (FGR) and their attitude toward actively managing these resources to strengthen the resilience of forest ecosystems to climate change. Respondents perceived pests and diseases to be the top-ranking threats to forests, followed by windstorms and drought, with differences across countries. They stated to be aware of the potential offered by managing FGR and indicated that they paid attention to origin and quality in their choice of planting material. Generally, respondents showed a positive attitude in using forest reproductive material foreign to the planting site, to better match the projected future climate conditions, introducing either a new native tree species or a new non-local genotype of a species already planted (keeping the same species but changing the source of planting material). However, forest reproductive material from local sources was largely preferred over non-local material (both genetically improved and not improved). Forest managers and owners may need to be exposed to more evidence of the potential benefits deriving from active adaptation and mitigation management of FGR before implementing adaptive measures. Also, more efforts should be invested in understanding perceptions and motivations of European forest owners and managers, in order to better tailor advice on optimal measures to counteract the detrimental effects of climate change.
\end{abstract}

Keywords Forest genetic resources $\cdot$ Forest management $\cdot$ Forest reproductive material $\cdot$ Climate change $\cdot$ Adaptation

\section{Introduction}

Communicated by Oliver Gailing.

Electronic supplementary material The online version of this article (https://doi.org/10.1007/s10342-020-01311-6) contains supplementary material, which is available to authorized users.

Barbara Vinceti

b.vinceti@cgiar.org

1 Bioversity International, Maccarese, Rome, Italy

2 Department of Biodiversity and Molecular Ecology, Research and Innovation Centre, Fondazione Edmund Mach, San Michele all'Adige, Italy

3 European Forest Institute, Joensuu, Finland

4 European Forest Institute, Bonn, Germany

5 INRAE, Écologie des Forêts Méditerranéennes (URFM), Avignon, France
Recent attempts to assess the impact of observed climate change on forest ecosystems in Europe highlighted changes in growth, in mortality associated with drought and in the distribution range of many species (Lindner et al. 2014). Predicting climate change impacts on forest ecosystems remains very challenging, given the level of uncertainty linked to the numerous simplifications applied in the modeling of biological and climate processes, and socioeconomic pathways (e.g., Dyderski et al. 2018; Reyer et al. 2017; Reyer 2015). Climate change projections for Europe indicate an increase in duration of drought periods in Southern and Central Europe; however, past climate scenario projections have systematically underestimated observed trends in warm extreme events (Lorenz et al. 2019). In the Mediterranean region, forest fires and droughts are projected to increase, while the boreal region is expected to experience enhanced 
forests growth and increasing risk of forest pests. Based on projections of the European Environment Agency (EEA 2017), Northern Europe is expected to face an increase in summer and winter precipitations and an increase in occurrence of extreme events, such as, for example, flooding and late frosts. In mountain regions, an upward shift of plant species is foreseen. On average, cold extremes are expected to decrease, but their intensity and duration might remain the same or increase under future climatic conditions (Rummukainen 2012).

Disturbances from abiotic and biotic pressures (windstorms, bark beetles and wildfires) increased during the twentieth century in Europe and are projected to become more frequent in the next decades (Seidl et al. 2014, 2017). Plant diseases are largely influenced by environmental conditions, so environmental changes are likely to impact on pathogens, on their hosts, and on the interaction between them (Sturrock et al. 2011).

Forest responses to environmental changes and adaptive processes are species-specific. They depend on the phenology and ecology of species and ecotypes, on the stand characteristics, on the competition regime, on forest structure (Reyer et al. 2009; Bolte et al. 2009) and on the characteristics of the distribution range of a species (Kremer, 2007). Tree species with a wide range in Europe will unlikely face extinction at species level, while some local tree populations could be lost, particularly those in marginal ecological sites and at the rear edge of the distribution (Fady et al. 2016). Tree species with scattered or limited distributions generally appear to be more vulnerable and may face important threats at the species level (Hubert and Cottrell 2007).

Managing genetic diversity has a key role in fostering tree adaptive responses to environmental changes and in mitigating the effects of pests and diseases (Alfaro et al. 2014; Fady 2015); thus, it could contribute to increasing overall resilience of forest ecosystems. This has been recognized by FAO, which launched a global plan of action for the conservation, sustainable use and development of forest genetic resources (FGR) in 2014 (FAO 2014).

The perception of forest owners and managers vis-à-vis the challenges posed to forests by abiotic and biotic pressures is critical to understand what strategies and approaches are actually being adopted to mitigate their effects and what options could be proposed when no action is being taken (Blennow 2012; Blennow et al. 2012; Sousa-Silva et al. 2018).

Projected climate changes appear to be greater in magnitude than the climate variability experienced by forest managers in the past, generating pronounced uncertainties. Evidence-based traditional forest management approaches may not propose effective future management solutions rapidly enough. Future climatic conditions may produce novel system states and dynamics, never experienced before; therefore, past practices would neither be applicable nor provide guidance (Stainforth et al. 2007). Furthermore, climate scenarios can be partly contradictory, and predictions are more robust at global or regional than local level. Forecasts are often presented in a format that is not easy to translate in precise recommendations for management at stand level (Lindner et al. 2014).

In decision-making processes about forest management, factors such as values, knowledge, trust, risk perception, desired outcomes, past hardships and beliefs come into play (Aubin et al. 2011; Hajjar and Kozak 2015).

A good number of studies have focused on understanding the views of forest-dependent communities and forest owners about climate change and their readiness to introduce changes in their forest management to foster adaptation of forest ecosystems to future climate conditions, especially in North America (Grotta et al. 2013; Hajjar et al. 2014; Lenart and Jones 2014; Rodriguez-Franco and Haan 2015) and Europe (Williamson et al. 2005; Blennow and Persson 2009; Blennow et al. 2012; Lawrence and Marzano 2013). Despite a different level of awareness about climate change between the two regions, some general findings emerge from the existing literature. Personal belief in climate change and a personal experience of its effects appear to be critical factors that stimulate adoption of adaptive measures in forest management (Blennow et al. 2012; Williamson et al. 2005). Forest owners, managers and forestry professionals seemed not inclined to make significant changes to their management in anticipation of climate change, but looked eager to learn more about ways this could affect their forests (Grotta et al. 2013) and understand better the benefits to be derived from active management (Lenart and Jones (2014). In some cases, other threats, such as pests and diseases, were felt as more pressing than climate change (Lawrence and Marzano 2013); in other cases, lack of financial support (Laakkonen et al. 2017) or lack of information and knowledge were presented as main disincentives and constraints (SousaSilva et al. 2016, 2018). In the case of private owners of small forest properties non-continuously managed by experts, it has been found that the prevailing view is to leave natural dynamics in forest ecosystems guide selfregulatory processes, without additional interventions (Mostegl et al. 2019).

In order to promote the uptake of adaptive measures to climatic changes by the forestry sector, policy-makers should consider several aspects in addition to information sharing: in particular the socioeconomic context that determines what is economically relevant in a specific system, the institutional and policy contexts and the development of techniques and tools to support a transition in forest management toward the implementation of adaptive measures (Andersson and Keskitalo 2018). 
A large part of published research on forests and climate change has focused on the potential shifts in tree species distribution, on the vulnerability of individual species, on the expected impacts of climate change on these and less on the specific adaptive measures recommendable for specific contexts (Keenan 2015). Evidence collected in the USA showed that the most accepted adaptive practices to climate change were those tested over long time, such as thinning and prescribed burning in highly dense forests (Lenart and Jones 2014).

Tree species selection is widely recognized as the main critical choice through which the capacity of forest ecosystems to withstand climatic changes is directly influenced (Blennow et al. 2012; Lawrence and Marzano 2013; Yousefpour and Hanewinkel 2015; Sousa-Silva et al. 2018); in addition, silvicultural treatments that enhance complexity of a stand and modify its age and structure have an influence on how forests respond to climate change (Jandl et al. 2019).

Despite the large amount of evidence on the critical role of FGR to foster adaptation in forest ecosystems (Alfaro et al. 2014), very few studies have examined the readiness of forest owners and managers in Europe to actively manage FGR, beyond tree species selection, to actively contrast the effects of environmental changes. Genetic adaptation to climate change is influenced directly by decisions on the type of regeneration approach used and the geographic origin and genetic composition of the planted material selected (Lefèvre 2004; Finkeldey and Ziehe 2004; Hosius et al. 2006; Ratnam et al. 2014; Fady et al. 2015).

Depending on the local context, different alternatives for regeneration can be considered: a) the promotion of natural regeneration where the pace of climate change is not drastically changing site conditions; b) the planting of best-adapted varieties together with those currently used; c) the use of assisted gene flow and assisted migration (as presented by Aitken and Whitlock 2013), which implies, respectively, the movement of forest reproductive material (FRM - seeds, plant parts such as cuttings and scions, and plants raised by means of seeds or propagated in vitro) within a species range or outside a species range, introducing planting material selecting from provenances and species adapted to the future climatic conditions of the planting site (Huber and Cottrell 2007).

Different forms of assisted migration can be implemented based on what are the goals (Williams and Dumroese 2013) and considering the boundaries of existing regulations. Substantial uncertainties are associated with this approach (McLachlan et al. 2007), due to lack of clarity about future climate scenarios, especially at the local scale, lack of robust seed transfer guidelines, risks of maladaptation and genetic pollution, potential disturbances to indigenous flora and fauna, risks of introducing new pathogens or exposing newly introduced species to new pathogens. The debate on assisted migration is mainly centered around ecological risks and benefits; however, divergent opinions may be related to fundamentally different views on nature, and more specifically, to the ethical aspects associated with the question of whether a deliberate management of natural systems or their selfadaptation should be encouraged (Aubin et al. 2011). Thus, opinions on what type and quality (e.g., origin, degree of improvement) of forest reproductive material should be used can be quite different and dependent on the socioeconomic context.

An assessment of these different views was carried out by Hajjar et al. (2014) who examined the opinions expressed by leaders of forest-dependent communities and the general public in two provinces of Canada, about different reforestation strategies in the face of climatic change; the strategies differed in their degree of reliance on biotechnology. It turned out that the views were aligned around a low acceptance for a passive strategy, which meant no planned action to buffer climate change effects. Replanting with local seeds was considered highly acceptable, while other strategies based on breeding and movement of seed outside of a species natural range were considered less acceptable. Solutions based on genetic engineering obtained the lowest acceptance. Examples of similar investigations are currently missing for Europe.

We tried to fill this gap by exploring the extent to which forest owners and managers are actively managing FGR as a strategy to adapt forests to climate change. We tried to understand what were the main forest threats of concern for forest owners and managers across Europe and then looked at the following aspects: a) What is the general knowledge of forest owners and managers about FGR? $b$ ) What is their attitude toward actively managing FGR to contrast the effects of climatic changes and of other threats? c) How do forest owners and managers consider genetic resources in their choices about forest regeneration?

\section{Methods}

We developed a survey targeting forest owners and managers across Europe. Respondents had the possibility to identify themselves or to answer anonymously. To maximize the rate of response, the survey was available in multiple European languages (English, Danish, Finnish, French, German, Italian and Spanish). The survey was created online using Surveymonkey (https://www.surveymonkey.com/) and was accessible from October 17, 2016, to January 31, 2017. The initiative was widely advertised through posts on websites, newsletters and social media accounts of institutions, programmes and research initiatives related to conservation and sustainable management of forests and FGR. Associations of 
forest owners and managers were also contacted. Reminders were sent at regular intervals.

Respondents had to provide information about their role, experience, level of activity, from local to international and type of entity represented. The content of the questionnaire is in the Supplementary Material.

Forest owners and managers were asked to indicate their perception about the main threats affecting forests today and in the future. For this, they had to choose among the following pre-defined threat categories: drought, fire, freezing rain/ ice storms, overexploitation of forests, pests and diseases, wind storms. More than one threat could be identified, and a possibility was given to add other, unlisted types of threats. In addition, respondents were asked to define the type of management intensity they were referring to in their answers using pre-defined forest management categories, described in the text of the survey (see Supplementary Material). Various questions referred to the degree of consideration of FGR in management decision, in particular with regard to choices around forest regeneration options, sources and quality of FRM. Follow-up questions regarding the sources of planting material were reserved to those who indicated artificial regeneration as a prevalent management choice.

We used descriptive statistics to examine responses to each question, looking at overall patterns emerging at the regional (European) level. A multiple correspondence analysis (MCA) was performed to reveal the underlying structure of the data. Moreover, a correspondence analysis (CA) was applied on contingency tables of countries to investigate the association between the perception regarding current and future threats to forest and the geographic location of respondents. Subsequently, a hierarchical clustering on principal components (HCPC) was applied on the results of the CA to identify groupings of countries with similar responses for each question in the survey. Conditional inference trees (CITs) were applied to individual questions to reveal patterns in responses. They perform recursive partitioning of the sample, based on statistical significance tests. Missing values were discarded from the analysis ( $14 \%$ of the records in the original dataset had to be removed due to missing information; the sample used for the analysis is presented in Table 1) Statistical analyses were performed using the statistical software R (R Core Team, 2017) and the FactomineR, factoextra and partykit packages (Le et al. 2008; Kassambara and Mundt 2017; Hothorn and Zeileis 2015).

\section{Results}

A total of 204 forest owners (98) and managers (106) from 15 European countries responded to our survey (see Table 1). Most respondents presented their personal views, and a minority represented the view of associations or
Table 1 Description of the sample of respondents to the survey

\begin{tabular}{llll}
\hline Professional profile & Forest owner & 98 & $48.0 \%$ \\
& Forest manager & 106 & $52.0 \%$ \\
& Total & 204 & \\
& Individuals & 180 & $88.2 \%$ \\
& Associations & 15 & $7.4 \%$ \\
& Other entities* & 9 & $4.4 \%$ \\
Scale of activity & Local level & 75 & $36.8 \%$ \\
& Regional (within-country) & 71 & $34.8 \%$ \\
& level & & \\
& Country level & 52 & $25.5 \%$ \\
& International level & 6 & $2.9 \%$ \\
& Countries represented & 15 & \\
Years of experience & $<5$ years & 10 & $4.9 \%$ \\
& 5-10 years & 29 & $14.2 \%$ \\
& 10-20 years & 45 & $22.1 \%$ \\
& $>$ 20 years & 120 & $58.8 \%$ \\
Ownership of forest land & Privately owned/managed & 164 & $80.4 \%$ \\
& Public land & 20 & $9.8 \%$ \\
& Other** & 20 & $9.8 \%$ \\
\hline
\end{tabular}

*Other entities $=$ representative of forest service, legal representation of regional association of forest owners/land owners, representative of interest group of forest/land owners, forest service, operations manager for a forestry company

**Other $=$ representative of stakeholder organization (e.g., forest owners), researcher in forest management, consultant, advisor, extension agent for private landowners. $N B$. All respondents without a specified association with a country location were removed

other entities (e.g., national forest services, other public bodies, forest companies). Responses mainly referred to the local and regional (sub-national) levels (72\%). Only a few responses (ca. 4\%) referred to the international level. The majority of respondents had a long-term experience (>20 years) (56\%) and were from the private sector $(80 \%)$ (Table 1). The prevalent form of management intensity (see definitions in Supplementary Material, in question 3 of the survey) applied by respondents (indicated by $72 \%$ of all respondents) corresponded to a combined economic objective/site-adapted forestry (see definition in Supplementary Material), followed by 'Intensive even-aged forestry' (indicated by $14 \%$ of respondents). The following categories were represented in much smaller proportions: 'Close-to-nature forestry' (9.6\%), 'Unmanaged forest nature reserve' (1\%), 'Short rotation forestry' (1\%), other (2.5\%; this category refers to cases of mixed approaches). We received most response from Austria (52), France (64) and Norway (31), followed by Germany (12), Italy (8) and Spain (9). From other countries (Belgium, Denmark, Finland, Iceland, Portugal, Romania, Slovenia, Sweden and the UK), we received five or less responses.

A MCA applied to all the survey questions combined did not reveal any clustering of respondents. The first two axes 
Fig. 1 Hierarchical clustering on factor map (HCPC). Country profiles are visualized in a space defined by different forests threats. Countries closely positioned on the factor map and belonging to the same cluster share a similar profile in terms of perception of threats expressed by individual respondents

\section{Factor map}

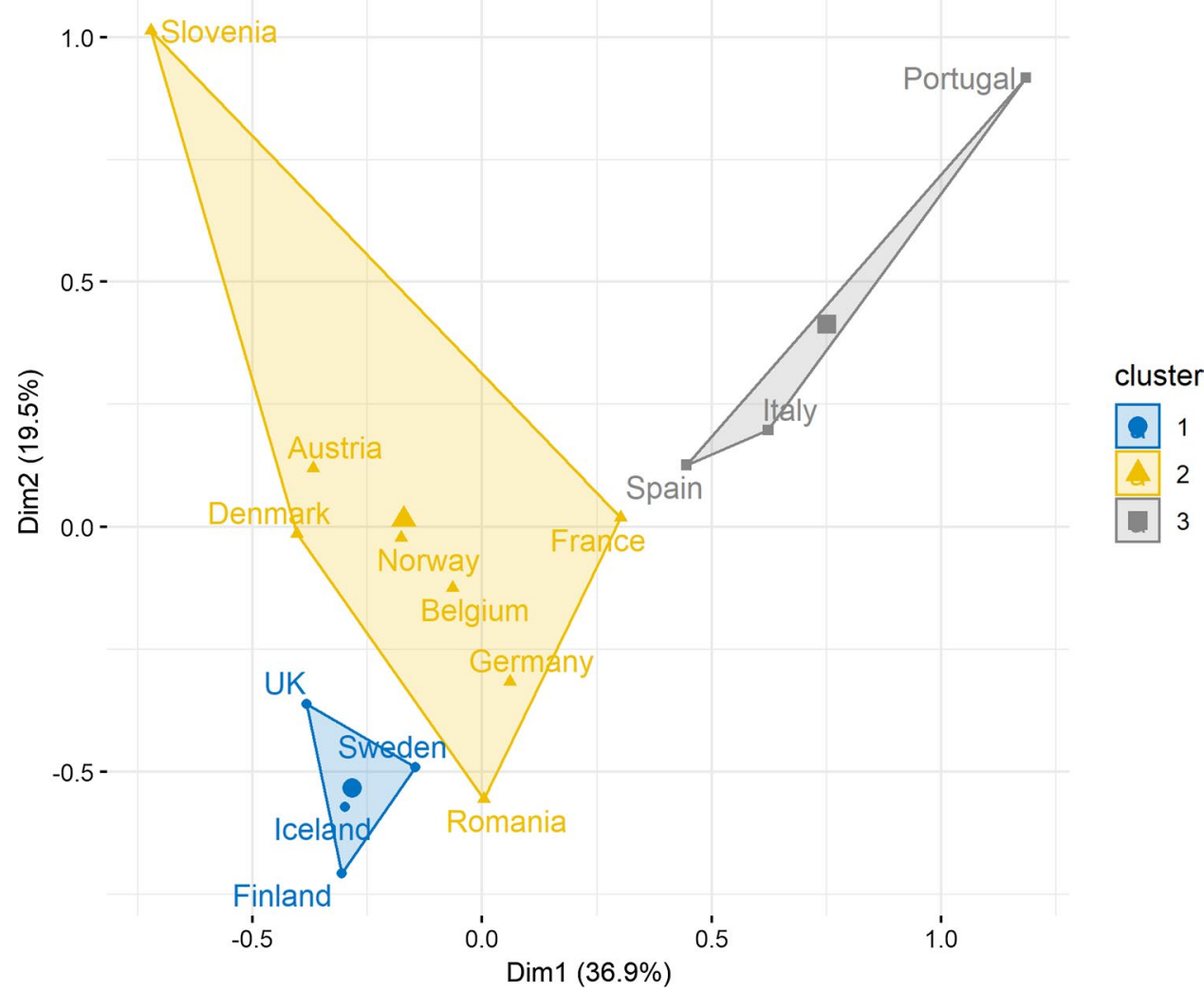

only explained $11.3 \%$ of the variation, and the cloud of individual respondents clustered at the center. Discarding from the analysis, the facultative questions with very low frequency of responses (that could undermine the analysis) did not improve the results. Consequently, individual questions were analyzed separately, looking for prevalent answers.

Based on the perceptions of survey respondents, the top-ranking threats to forests were considered to be pests and diseases, both today and in future $(34.8 \%$ and $32.6 \%$, respectively), windstorms ( $29.1 \%$ and $23.7 \%$, respectively) and drought (14.4\% and 19\%, respectively), followed by fire with much lower percentages (4.9\% and 7\%, respectively). The category 'Other threats' included threats indicated by respondents in addition to the pre-defined categories; most respondents referred explicitly to climate change as a current and future threat.

The HCPC on the factor map detected three main clusters of countries with a similar profile in terms of perception of threats. They are formed, respectively, by: (1) Spain-Italy-Portugal, (2) the UK-Iceland-Sweden-Finland and (3) all other countries (Fig. 1).

Results from the CA indicated that the two first axes explain $56.4 \%$ of the cloud total variability, so they represent a good part of the variability (Fig. 2). The distance between any row points or column points gives a measure of their similarity, so threats that have a similar profile among countries are positioned close to each other. The biplot reveals that there is a clear association between current and future perception of the importance of each threat, so the ranking of importance attributed to each threat is not changing in order of magnitude over time in the view of respondents.

Mediterranean countries such as France, Italy, Spain and Portugal perceive fire and drought as critical current and future threats. Slovenian respondents highlighted freezing events as a major threat (probably relating to the major ice storm that occurred in 2014 and has affected about 500,000 ha of forests). Norway, Germany and Belgium reported windstorms as a threat, while the category 'other threats' appeared associated mainly with northern European countries such as Finland, Iceland, Sweden and the UK. In most cases, people who chose 'other threats' specified 'climate change.' Pests and diseases were perceived as current and future threats across countries, with no particular geographic pattern.

A total of $86 \%$ of the respondents expressed the view that management of FGR could mitigate some of the future threats affecting forests, in particular pests and diseases and droughts. Other future concerns that could be addressed by proper use of FGR, according to the respondents, were climate change and issues related to low potential resilience of 
Fig. 2 Results from the correspondence analysis (CA) on current and future forest threats (red color) in the different countries (blue color) to which the survey responses refer. The distance between any row points or column points gives a measure of their similarity (or dissimilarity). Threats that have a similar profile among countries are close to each other. In the same way, those countries positioned close to each other have a similar threat profile. Both current and future threats are projected on the plane. Other threats $=$ respondents expressed independently additional concerns; these mainly referred to climate change as an element of current and future threat. (Color figure online)

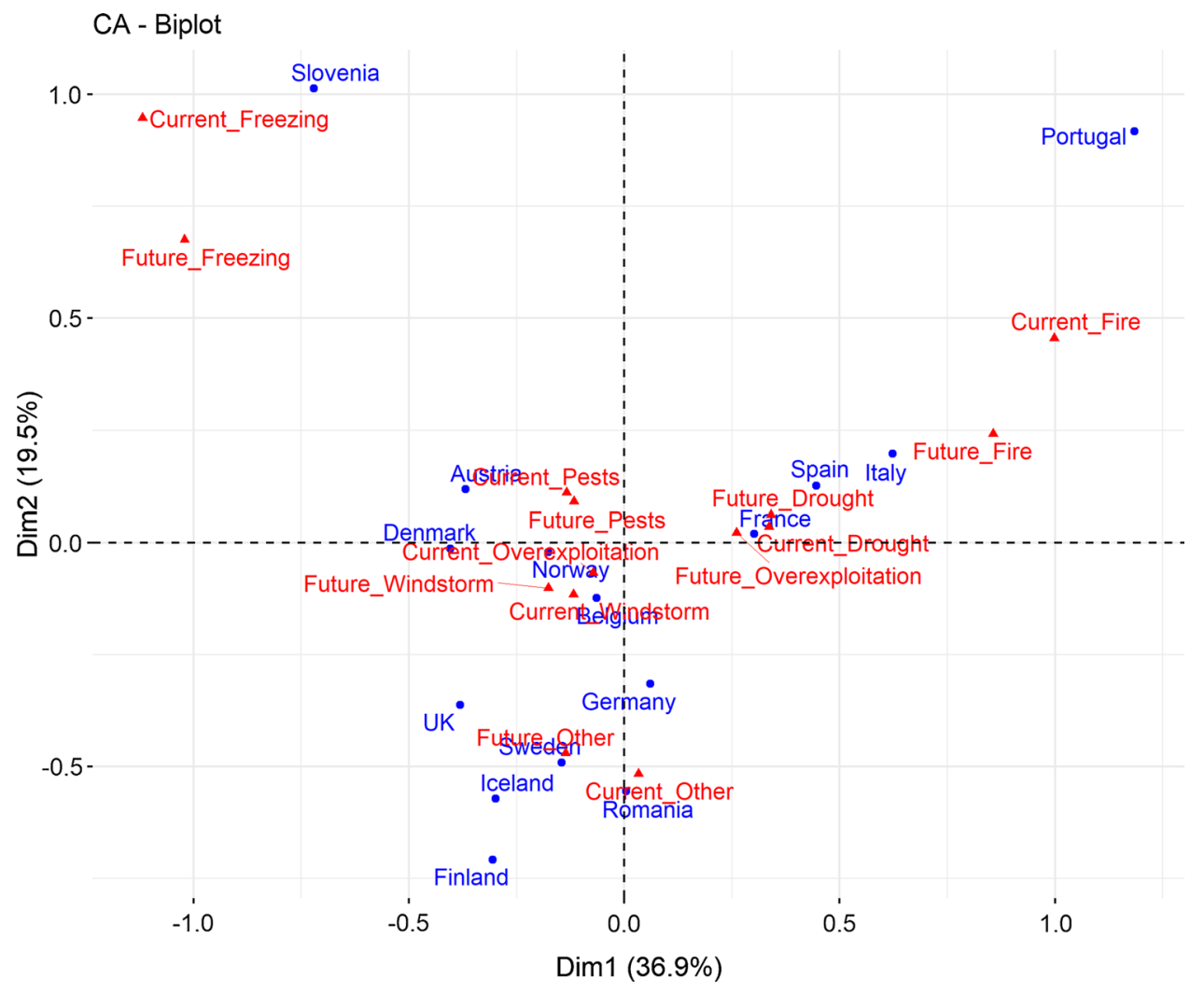

forest stands with limited genetic diversity (including breeding populations). The responses also indicated some awareness among respondents about the linkages between different quality of wood and non-wood products and their genetic origin. A total of $75 \%$ of the respondents stated explicitly that they took into consideration genetic aspects in their forest management.

Respondents applied artificial regeneration (43\% of respondents) and natural regeneration ( $41 \%$ of respondents) to a similar extent. Coppicing was indicated by $6 \%$ of the respondents, while $10 \%$ of the respondents indicated using a combination of artificial regeneration, self-seeding and coppice, according to characteristics of the species considered, of the planting site and climatic conditions. The responses revealed a geographical pattern, with a group of countries, mainly although not exclusively from Northern Europe (Denmark, Finland, Iceland, Norway, Sweden) where artificial regeneration is largely prevalent, and a second group characterized by a more widespread use of natural regeneration and coppice (Figure S1 in Supplementary Material).

When opting for artificial regeneration, respondents indicated that aspects of genetic quality of FRM (attention to best origin) were usually taken into account for both conifers and broadleaves across all countries. After excluding missing values, $97 \%$ respondents said yes or often for conifers and $74 \%$ said yes or often for broadleaves.
We then examined the attitude of forest owners and managers toward moving FRM in order to optimize the matching between future site conditions and the selected FRM. The survey questions on this subject were addressed to all respondents, regardless of what forest regeneration approach they were adopting, in order to understand their general inclination. The proportion of answers falling in the different categories of responses is not randomly distributed. Responses are concentrated around a middle position ('partially positive') for both the movement of tree species and the movement of tree provenances within the same species (Fig. 3), with a significantly higher value assigned to moving a tree species than moving provenances. Respondents rated the option of 'using a tree species not present before in the planting site' as partially positive in ca. $45 \%$ of the cases, versus 'using a provenance not present before in the planting site' as 'partially positive' in $32 \%$ of the cases. However, by adding up the categories 'rather positive' and 'very positive,' the option of 'using a provenance not present before in the planting site' scored slightly higher than 'using a tree species not present before in the planting site' (40\% vs. $35 \%$ ). By combining all three categories, 'partially positive,' 'rather positive' and 'very positive,' the option of 'using a provenance not present before in the planting site' received more support than the alternative option, with about $10 \%$ more votes. 

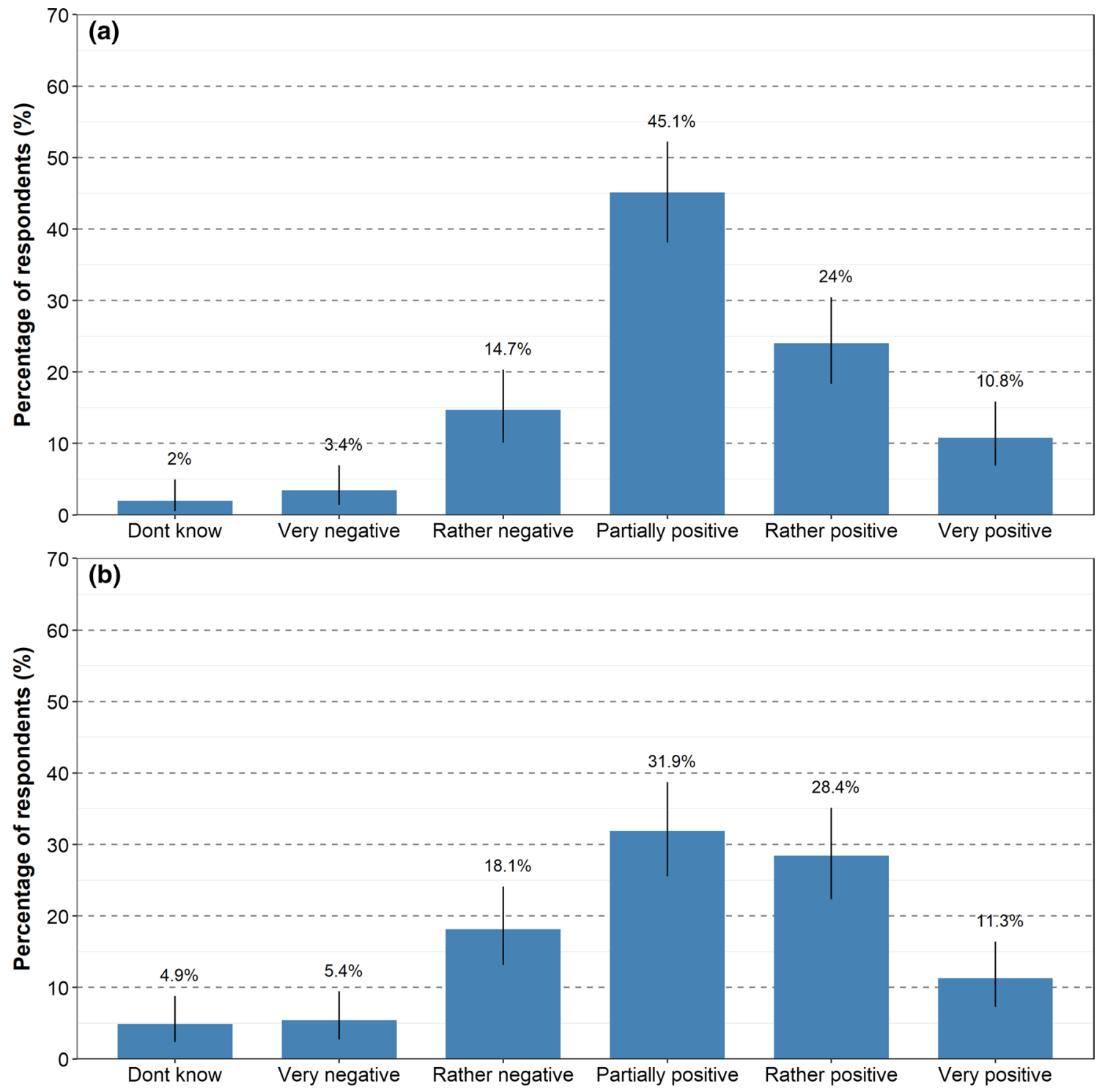

Fig. 3 Perception of forest owners and managers (expressed as \% of respondents; 204 in total), about a using forest reproductive material of a tree species not present before in the planting site; $\mathbf{b}$ using forest

We repeated the analysis above comparing responses of those currently favoring natural regeneration versus those using artificial regeneration. We found that those already making use of artificial regeneration as a prevalent approach had a higher positive attitude toward moving both species and provenances (for respondents operating at the local level, 'very positive' and 'positive' responses were four times more numerous than those of respondents making use of natural regeneration) and also a significantly lower negative attitude toward these two options, compared to forest owners and managers who privileged natural regeneration.

Most forest owners and managers $(75 \%)$ indicated that they were informed about the characteristics and benefits reproductive material of a tree provenance not present before in the planting site

that can be derived from the use of improved FRM. ${ }^{1}$ The majority of the forest owners and managers (73\%) indicated that they were aware of the existence of some good local provenances of species of interest for them, from native seed stands. Furthermore, aspects of quality of provenances

\footnotetext{
${ }_{1}$ Improved forest reproductive material has been tested and selected in order to obtain benefits, such as increased productivity, improved timber quality, better resilience to climatic conditions, pests and diseases. In particular, genetic improvement can vary from provenance selection, seed stand establishment, establishment of seedling or clonal seed orchards with controlled pollination, up to advanced breeding techniques and genetic engineering.
} 
Fig. 4 Extent to which aspects of quality (best provenances) are considered in the choice of forest reproductive material for conifers and broadleaves. Not applicable: the context does not enable to carry out a selection

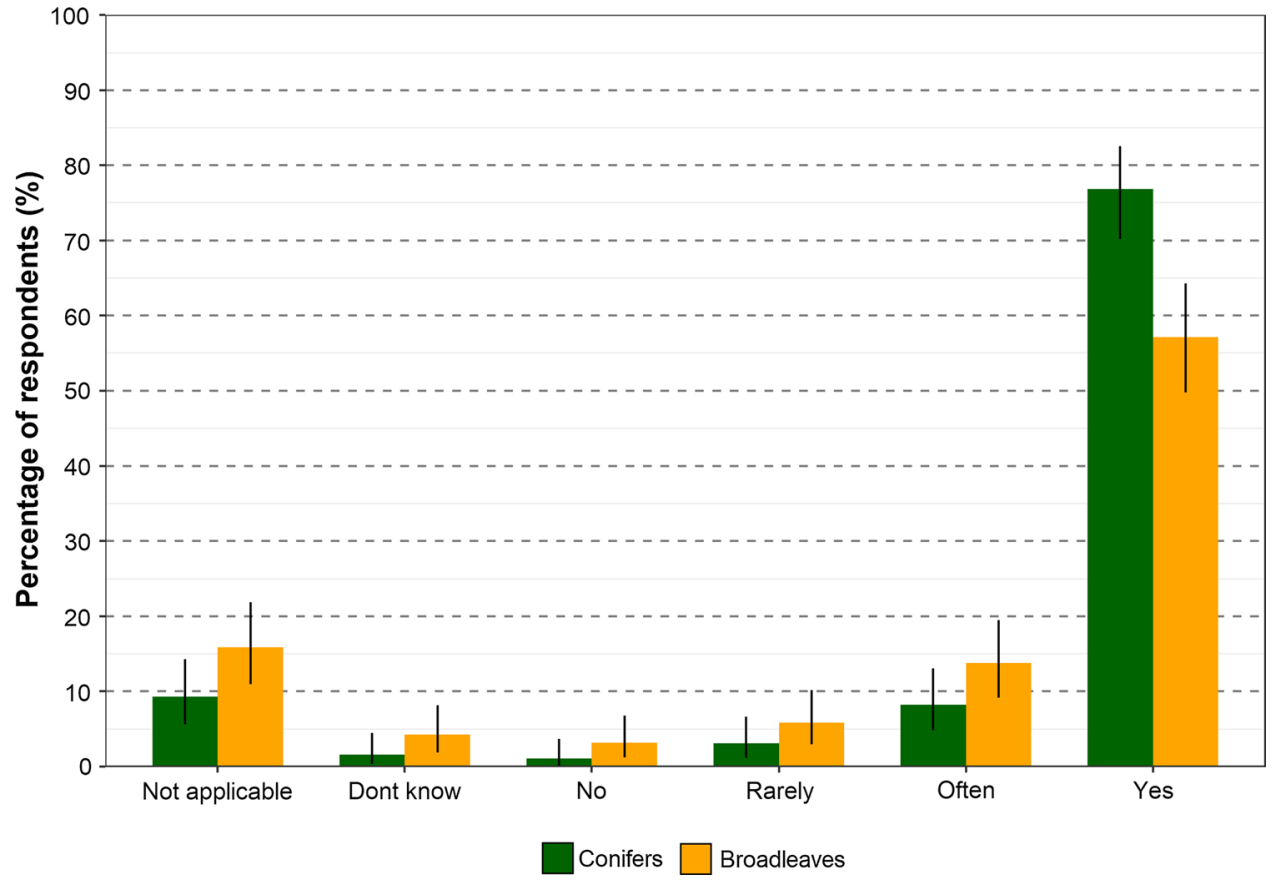

turned out to be commonly considered in the choice of FRM (Fig. 4), both for conifers and broadleaves.

Regarding access to FRM, a total of $65 \%$ of the respondents indicated they had access to improved FRM; $24 \%$ of the respondents did not have access to improved FRM, while the remaining fraction was not informed.

With regard to choices of different types of FRM, local material was generally preferred over "non-local material.' A 2-sample $t$ test did not reveal any preference on whether 'improved material' was preferred over material not improved.

The majority of forest owners and managers (83\%) who opted for artificial regeneration had preferences for some provenances they wished to plant. However, in half of the cases, it was the regulatory framework that defined what could be planted; personal choices came into play in $37 \%$ of cases, while other factors played a role in $13 \%$ of cases. These included cases of a selection of provenances guided by professional experts, by scientific guidelines or based on a combination of different actors or/and conditions.

\section{Discussion}

We asked forest owners and managers about their perception about main threats to forests and their responses reflected well the distinctive predominant threats at regional level. The most highly ranked threats in our survey were pests and diseases and windstorms, followed by drought and fire. Available data on the relative areas of forest affected by different types of disturbance show that pests and insects have an influence on the largest proportion of the forest cover (ca. $1.1 \%$ ), followed by storms, wind and snow (0.6\%) (data from FOREST EUROPE 2015 presented in the European Environmental Agency report of 2016). Fires affect ca. 0.1\% of the forest cover in Europe; however, $85 \%$ of fires are in southern Europe, so their occurrence has a strong regional pattern. The fact that the option 'climate change' was not available among the closed answers (to avoid the complexity otherwise associated with the concept of climate change) has likely limited the choice of this response. Nevertheless, some respondents explicitly referred to climate change (reporting this under the option 'Other') and the types of threats most cited (e.g., increases in pests and diseases and to increased frequency of fires and droughts) are largely associated with climate change.

The large majority of respondents (more than two thirds) indicated that they are aware of the potential role of FGR management in addressing climate change and mitigate other future threats for forests, in particular the influence of pests and diseases and of drought. This level of awareness may be the result of a close interaction, in some European countries targeted by our survey, between scientists involved in research on FGR and regional and national platforms of forest owners and managers. However, even excluding some countries where the dialogue between scientist and managers is most active (e.g., France, Austria, Norway), results do not change. This may therefore be a reflection of the work of initiatives such as the European Programme on Forest Genetic Resources (EUFORGEN), which has been running for more than 25 years and has focused significantly on knowledge sharing and awareness raising across European countries. 
For what regards motivations to adopt adaptive measures, a recent study carried out targeting small-scale private forest owners in Austria revealed the motivations of forest owners to adopt adaptive management measures, their perception of climate change and their adaptability to it; the objective was to develop appropriate information campaigns, advisory services and monetary incentives (Mostegl et al. 2019). Results showed that climate change was a fairly well-known issue, and slightly more than half of the respondents were convinced that adaptation measures had to be promptly set in place. However, small-scale private forest owners turned out to be a very inhomogeneous group, with three distinct clusters identified, who reacted differently to the management options and incentives proposed: 'utility oriented,' 'recreation oriented' and 'tradition conscious' forest owners. Our data did not reveal any underlying structure that could lead to identify distinct typologies of forest owners and managers; however, this was probably due to the broad diversification of responses associated with the multicountry nature of our survey. Anyhow, most findings point to the need to design locally adapted solutions, including tailor-made advisory services. The biological and socioeconomic context (including the industrial sector) defines what management solutions are locally preferable to enhance the resilience of forest stands in light of climate change. For instance, planting a better-adapted tree provenance may be a more efficient solution than changing the tree species to be planted; in other cases, specific forest management practices applied after the stand establishment are equally critical in ensuring long-term resilience as the modifications in species and provenances composition. Examples of adaptive management practices are a reduced planting density to mitigate moisture stress, an increased thinning and use of prescribed fire to reduce the risks of insect and diseases outbreaks in overstocked stands, an increased thinning in areas closer to urban settlements to avoid risk of fire. Mixed-species forestry is an important option to adapt forests to climate change (Bauhus et al. 2017). Even if mixtures do not provide an effective insurance in all situations, they contribute to reduce the impact of disturbance agents and help in preventing complete losses. However, distributing risks across several tree species may not be necessarily a successful strategy in areas with high tree species diversity as a starting condition or where climate and soils may be suitable only for a very limited range of tree species. What matter are the specific traits of the individual species mixed and the nature of the disturbance. How a mix of provenances would perform versus a mix of tree species depends largely on the local environmental conditions and choices are bounded by management objectives. The identification of most viable solutions requires a careful assessment of projected climate changes and vulnerabilities, and a discussion with stakeholders about most promising options (Seidl et al. 2011, Halofsky et al. 2018).

We examined the characteristics of the pool of respondents from 15 countries in Europe, to assess whether the sample was balanced. The respondents over-represent private versus public ownership, but this is in line with the characteristics of forest ownership across Europe: 13 out of the 15 countries sampled in this study are from Northern Europe, Central-West Europe and South-West Europe (based on the FOREST EUROPE clustering of countries), where private ownership of forests ranges from 60 to over $70 \%$ of the total forest area (FOREST EUROPE 2015). A constraining element in the analysis is the unbalanced number of respondents per country, which limited the possibility to look at individual countries, so most results are aggregated. The overall analyses revealed some grouping of responses by countries with regard to perception of threats to forests, but the analysis of all individual responses to all questions failed to show a structure in the data. This means that the grouping of similar responses varied among different questions.

In our survey, forest owners and managers were asked to indicate their prevalent approach for forest regeneration and responses showed a balance between natural and artificial regeneration. Considerable differences between individual countries and regions emerged, as reflected in forest statistics. Nowadays, regeneration by planting dominates in Northern and Central-East Europe, while natural regeneration is prevalent in the other European regions; about $68 \%$ of the total European forest area is regenerated naturally or expands spontaneously (FOREST EUROPE 2015). Coppicing is common only in Southern European countries. According to the Forest Resource Assessment released by FAO (FRA 2015), in the countries represented in our survey, artificial regeneration is used for $40-50 \%$ of the forest area in Northern and Central-West Europe, and for less than 15\% in South-West European countries. Indeed, choices around forest regeneration methods and, in case of artificial regeneration, around sources of FRM, are highly influenced by the characteristics of the forest ecosystem considered and the role of forestry in the economy of a particular country.

In case of use of artificial regeneration, it is interesting to see in our respondents a prevalent positive inclination toward moving FRM (both species and provenances) to match expected future climate conditions, with a slightly higher overall preference for moving tree species rather than provenances. This positive attitude toward moving FRM was more pronounced in those forest users and managers already making use of artificial regeneration. However, this finding is partly contradicted by the responses to a question on a related topic provided by those respondents relying on artificial regeneration; when asked to indicate what FRM they favored, the largely preferred choice of FRM was for local material over non-local material (both improved and 
Table 2 Preferred options in the selection of forest reproductive material (FRM) (more than one option could be chosen). The highest values (corresponding to FRM of local origin) are marked in bold

\begin{tabular}{llc}
\hline Type of FRM & N. respondents & \% respondents \\
\hline Local & 87 & $\mathbf{3 9 . 9 1}$ \\
Non-local & 10 & 4.59 \\
Local improved & 96 & $\mathbf{4 4 . 0 4}$ \\
Non-local improved & 25 & 11.47 \\
\hline
\end{tabular}

not improved). The most selected choice in absolute terms was for improved, local FRM, which indicates a lower appreciation for foreign material. The only results that could be compared to these findings derive from the study by Hajjar et al. (2014) in western Canada, focused on assessing perception of threats posed by climate change, targeting leaders of forest-dependent communities and the general public. The findings from Hajjar et al. (2014) revealed a low acceptance for a passive approach (i.e., no intervention) and a high acceptance of replanting with local seeds. Acceptance of strategies that involve more manipulation, such as breeding, use of non-local seeds, moving of seeds outside of a species' natural range was lower.

Scientists are increasingly testing and proposing new management solutions to increase the adaptability of forests to climate change. Among these, the option to plant tree species or provenances in areas where they are not occurring today, but that are expected to become suitable in future, is increasingly considered. This strategy is called assisted migration or assisted gene flow, depending on whether a species is planted within its current distribution range or outside (Aitken and Whitlock 2013), and it is based on evidence generated by genomic studies that show adaptation to particular environmental conditions (e.g., drought or heat) at local to regional scales (Aubin et al. 2016). Our results show that despite an increasing awareness on the role of FGR management and a stated positive inclination for FRM movement as a measure to foster adaptation in forest ecosystems, there is a certain resistance to introduce foreign planting material and a preference for FRM of local origin (Table 2).

Indeed, forest managers may need to see more research evidence of potential benefits to be obtained from moving FRM, before taking a more proactive attitude in this regard. As observed by other authors (Lenart \& Jones 2014), widespread support tends to the be reserved to those adaptive management practices tested over decades, while those that most directly affect the expansion of plant species outside their current range are less supported. Nevertheless, FRM has been moved in trade considerably in the past (Koskela et al. 2014; Jansen et al. 2019). However, tracking and recording of performance were missing in many cases, so evidence on outcomes is not available.

With regard to practice, the large majority of respondents to our survey indicated that, in case of artificial regeneration, they pay attention to the selection of tree species provenances with optimal characteristics, for both conifers and broadleaves across all geographies, so this is another indication that awareness on the importance of FGR is growing. Access to improved material did not seem to be a major constraint, especially for conifers. According to a recent modeling study, the economic benefits of using improved FRM from seed orchards greatly outweigh the additional cost of the planting material due to a significant increase in productivity across diverse site conditions. However, in contexts where forests mainly provide services other than production, the cost of high-quality FRM may be excessive compared to the profits that can be obtained from forest products, and this may be an obstacle for the active implementation of practices to foster adaptation to environmental changes.

Other constraints may derive from a lack of specificity in the recommendations guiding use of FRM in light of climate change and their potentially limited predictive capacity about performance of the FRM transferred, due to different reasons. FRM transfer guidelines have been mostly based on present or past climatic conditions and, in addition, a great amount of uncertainty characterizes future climate projections; habitat similarity for the transferred FRM is assessed mainly in relation to climatic factors, neglecting other important parameters, such as soil characteristics and interactions with other species and provenances; phenological responses may be very different across tree species in reaction to the same climatic change and research has not investigated sufficiently if large differences in response exist also among genotypes within the same species; heritable variation in adaptive traits is partly related to epigenetics (Konnert et al. 2015). Furthermore, FRM is increasingly traded across countries, but national laws focus only on its production and commercialization and do not regulate its use, so they do not assist in defining where the imported FRM should be planted. There are exceptions in some countries where national laws provide recommendations to forest owners on the use of FRM. These recommendations are all compliant with the Council Directive 1999/105/EC, and in some countries, they include more restrictive rules for FRM transfer into and between ecoregions (e.g., in Bulgaria, Cyprus, Croatia, Estonia, France, Lithuania, Norway, Slovakia, Slovenia, Sweden, the UK, Serbia, Poland); in others, recommendations define what FRM can be used based on species adaptation to site conditions (Belgium, Bulgaria, Finland, France, Greece, Lithuania, Slovenia) (Konnert et al. 2015). However, in all these cases, recommendations tend to be based on provenance regions whose boundaries were defined through research in provenance trials established 
without taking into consideration climate change responses in the design.

Expanding the view to adaptive management measures in a broader sense, a recent systematic review of the scientific literature by Hagerman and Pelai (2018) supports the view that the majority of recommendations on how to respond to climate change with forest management are too generic and vague, therefore difficult to put into practice in contexts with specific socio-ecological characteristics. The authors thus flagged the need to develop recommendations tailored to local needs, taking into account the specificities of the contents for which they are proposed, focusing on management solutions that enable to deal with uncertainty and incorporate different perspectives.

\section{Conclusions}

The European forest owners and managers targeted in this study perceived pests and diseases, windstorms and drought as the main threats of concern for forest ecosystems, with significant regional differences. Choices about FRM are very critical, and aspects of quality (best provenances) are considered by forest owners and managers in their selection of planting material, for both conifers and broadleaves. We found a generally positive attitude in moving FRM that is new to the planting site, in order to match the predicted future climate conditions, for both tree species and tree provenances. However, despite the stated positive inclination to moving FRM, the preferred choice of FRM was for local material over non-local material (both improved and not improved). This indicates a trust that local FRM will perform well under future climate conditions. This expectation may be over-optimistic, if global temperatures pass the $2{ }^{\circ} \mathrm{C}$ threshold of the 2015 Paris Agreement. Forest managers may need to be exposed to more research evidence of potential benefits deriving from the management of genetic diversity in planting material, both from local and foreign sources, before undertaking active adaptation and mitigation measures.

Acknowledgements This research was part of the GenTree project which has received funding from the European Union's Horizon 2020 Research and Innovation Programme under Grant Agreement No. 676876. We acknowledge the contribution of Michele Bozzano, Ewa Hermanowicz and Joanne Fitzgerald in the design of the survey.

Author's contribution $\mathrm{BV}, \mathrm{NL}$ and PJV contributed to the design and set up of the survey. MM, BV and NL performed data cleaning and analysis. BV wrote the manuscript with the help of PJV, BF and ML.

Availability of data The data that support the findings of this study are available from the corresponding author [BV], upon reasonable request.

\section{Compliance with ethical standards}

Conflict of interest The authors declare that there is no conflict of interest regarding the publication of this article.

Open Access This article is licensed under a Creative Commons Attribution 4.0 International License, which permits use, sharing, adaptation, distribution and reproduction in any medium or format, as long as you give appropriate credit to the original author(s) and the source, provide a link to the Creative Commons licence, and indicate if changes were made. The images or other third party material in this article are included in the article's Creative Commons licence, unless indicated otherwise in a credit line to the material. If material is not included in the article's Creative Commons licence and your intended use is not permitted by statutory regulation or exceeds the permitted use, you will need to obtain permission directly from the copyright holder. To view a copy of this licence, visit http://creativecommons.org/licenses/by/4.0/.

\section{References}

Aitken SN, Whitlock MC (2013) Assisted gene flow to facilitate local adaptation to climate change. Annu Rev Ecol Evol 44:367-388

Alfaro RI, Fady B, Vendramin GG, Dawson IK, Fleming RA, SáenzRomero C, Lindig-Cisneros RA, Murdock T, Vinceti B, Navarro CM, Skrøppa T, Baldinelli G, El-Kassaby YA, Loo J (2014) The role of forest genetic resources in responding to biotic and abiotic factors in the context of anthropogenic climate change. For Ecol Manag 333:76-87

Andersson E, Keskitalo ECH (2018) Adaptation to climate change? Why business-as-usual remains the logical choice in Swedish forestry. Glob Environ Change 48:76-85

Aubin I, Garbe CM, Colombo S, Drever CR, McKenney DW, Messier C, Pedlar J, Saner MA, Venier L, Wellstead AM, Winder R, Witten E, Ste-Marie C (2011) Why we disagree about assisted migration: ethical implications of a key debate regarding the future of Canada's forests. For Chron 87:755-765

Aubin I, Munson AD, Cardou F, Burton PJ, Isabel N, Pedlar JH, Paquette A, Taylor AR, Delagrange S, Kebli H, Messier C, Shipley B, Valladares F, Kattge J, Boisvert-Marsh L, McKenney D (2016) Traits to stay, traits to move: a review of functional traits to assess sensitivity and adaptive capacity of temperate and boreal trees to climate change. Environ Rev 24:164-186

Bauhus J, Forrester DI, Gardiner B, Jactel H, Vallejo R, Pretzsch H (2017) Ecological stability of mixed-species forests. In: Mixedspecies forests, pp 337-382

Blennow K (2012) Adaptation of forest management to climate change among private individual forest owners in Sweden. For Policy Econ 24:41-47

Blennow K, Persson J (2009) Climate change: motivation for taking measure to adapt. Glob Environ Change 19:100-104

Blennow K, Persson J, Tomé M, Hanewinkel M (2012) Climate change: believing and seeing implies adapting. PLoS ONE 7(11):e50182. https://doi.org/10.1371/journal.pone.0050182

Bolte A, Ammer C, Löf M, Madsen P, Nabuurs G-J, Schall P, Spathelf P, Rock J (2009) Adaptive forest management in central Europe: climate change impacts, strategies and integrative concept. Scand J For Res 24:473-482

Dyderski MK, Paź S, Frelich LE, Jagodziński AM (2018) How much does climate change threaten European forest tree species distributions? Glob Chang Biol 24:1150-1163

Europe Environment Agency (EEA) (2017) Climate change, impacts and vulnerability in Europe 2016. An indicator-based report. EEA Report. No 1/2017 
Fady B, Cottrell J, Ackzell L, Alía R, Muys B, Prada A, GonzálezMartínez S (2015) Forests and global change: What can genetics contribute to the major forest management and policy challenges of the twenty-first century? Reg Environ Chang 16:927-939

Fady B, Aravanopoulos FA, Alizoti P, Mátyás C, von Wühlisch G, Westergren M, Belletti P, Cvjetkovic B, Ducci F, Huber G, Kelleher CT, Khaldi A, Bou Dagher Kharrat M, Kraigher H, Kramer K, Mühlethaler U, Peric S, Perry A, Rousi M, Sbay H, Stojnic S, Tijardovic M, Tsvetkov I, Varela MC, Vendramin GG, Zlatanov T (2016) Evolution-based approach needed for the conservation and silviculture of peripheral forest tree populations. For Ecol Manag 375:66-75

FAO (2014) Global plan of action for the conservation, sustainable use and development of forest genetic resources. FAO Rome. http://www.fao.org/3/a-i3849e.pdf

FAO (2015) Global Forest Resources Assessment. FAO Rome

Finkeldey R, Ziehe M (2004) Genetic implications of silvicultural regimes. For Ecol Manag 197:231-244

FOREST EUROPE (2015) State of Europe's Forests 2015. http:// foresteurope.org/state-europes-forests-2015-report/

Grotta AT, Creighton JH, Schnepf C, Kantor S (2013) Family forest owners and climate change: understanding, attitudes, and educational needs. J For 111:87-93

Hagerman SM, Pelai R (2018) Responding to climate change in forest management: two decades of recommendations. Front Ecol Environ 16:579-587

Hajjar R, Kozak RA (2015) Exploring public perceptions of forest adaptation strategies in Western Canada: implications for policy-makers. For Policy Econ 61:59-69

Hajjar R, McGuigan E, Moshofsky M, Kozak RA (2014) Opinions on strategies for forest adaptation to future climate conditions in western Canada: surveys of the general public and leaders of forest-dependent communities. Can J For Res 44:1525-1533

Halofsky JE, Andrews-Key SA, Edwards JE, Johnston MH, Nelson HW, Peterson DL, Schmittg KM, Swanstonh CW, Williamson TB (2018) Adapting forest management to climate change: the state of science and applications in Canada and the United States. For Ecol Manag 421:84-97

Hubert J, Cottrell J (2007) The role of forest genetic resources in helping British forests respond to climate change. Forestry Commission Information Note 86. Forestry Commission, Edinburgh

Hosius B, Leinemann L, Konnert M, Bergmann F (2006) Genetic aspects of forestry in the Central Europe. Eur J For Res 125:407-417

Hothorn T, Zeileis A (2015) Partykit: a modular toolkit for recursive partytioning in R. J Mach Learn Res 16:3905-3909

Jandl R, Spathelf P, Bolte A, Prescott CE (2019) Forest adaptation to climate change-is non-management an option? Ann For Sci 76:48

Jansen S, Konrad H, Geburek T (2019) Crossing borders-European forest reproductive material moving in trade. J Environ Manag 233:308-320

Kassambara A, Mundt F (2017) factoextra: extract and visualize the results of multivariate data analyses. $\mathrm{R}$ package version 1.0.5. https://CRAN.R-project.org/package $=$ factoextra

Keenan RJ (2015) Climate change impacts and adaptation in forest management: a review. Ann For Sci 72:145-167. https://doi. org/10.1007/s13595-014-0446-5

Konnert M, Fady B, Gömöry D, A'Hara S, Wolter F, Ducci F, Koskela J, Bozzano M, Maaten T, Kowalczyk J, European Forest Genetic Resources Programme (EUFORGEN) (2015) Use and transfer of forest reproductive material in Europe in the context of climate change. European Forest Genetic Programme (EUFORGEN), Bioversity International, Rome, Italy. ISBN 978-92-9255-031-8

Koskela J, Vinceti B, Dvorak W, Bush D, Dawson IK, Loo J, Kjaer ED, Navarro C, Padolina C, Bordács S, Jamnadass R, Graudal L,
Ramamonjisoa L (2014) Utilization and transfer of forest genetic resources: a global review. For Ecol Manag 333:22-34

Kremer A (2007) How well can existing forests withstand climate change? In: Koskela, Buck, Teissier's (eds) Climate change and forest genetic diversity-implication for sustainable forest management in Europe. European Forest Genetic Resources Programme (EUFORGEN). Bioversity International Rome

Laakkonen A, Zimmerer R, Kähkönen T, Hujala T, Takala T, Tikkanen J (2017) Forest owners' attitude towards pro-climate and climateresponsive forest management. For Policy Econ 87:1-10

Lawrence A, Marzano M (2013) Is the private forest sector adapting to climate change? A study of forest managers in North Wales. Ann For Sci 71:291-300

Le S, Josse J, Husson F (2008) FactoMineR: an R package for multivariate analysis. J Stat Softw 25:1-18. https://doi.org/10.18637/ jss.v025.i01

Lefèvre F (2004) Human impacts on forest genetic resources in the temperate zone: an updated review. For Ecol Manag 197:257-271

Lenart M, Jones C (2014) Perceptions on climate change correlate with willingness to undertake some forestry adaptation and mitigation practices. J For 112:553-563

Lindner M, Fitzgerald JB, Zimmermann NE, Reyer C, Delzon S, van der Maaten E, Schelhaas MJ, Lasch P, Eggers J, van der MaatenTheunissen M, Suckow F, Psomas A, Poulter B, Hanewinkel M (2014) Climate change and European forests: What do we know, what are the uncertainties, and what are the implications for forest management? J Environ Manag 15:69-83. https://doi. org/10.1016/j.jenvman.2014.07.030

Lorenz R, Stalhandske Z, Fischer EM (2019) Detection of a climate change signal in extreme heat, heat stress, and cold in Europe from observations. Geophys Res Lett 46:8363-8374

McLachlan JS, Hellmann JJ, Schwartz MW (2007) A framework for debate of assisted migration in an era of climate change. Conserv Biol 21:297-302

Mostegl NM, Probstl-Haider U, Jandl R, Haider W (2019) Targeting climate change adaptation strategies to small-scale private forest owners. For Policy Econ 99:83-99

R Core Team (2017) R: a language and environment for statistical computing. R Foundation for Statistical Computing, Vienna, Austria. https://www.R-project.org/

Ratnam W, Rajora OP, Finkeldey R, Aravanopoulos F, Bouvet J-M, Vaillancourt RE, Kanashiro M, Fady B, Tomita M, Vinson C (2014) Genetic effects of forest management practices: global synthesis and perspectives. For Ecol Manag 333:52-65

Reyer C (2015) Forest productivity under environmental change-a review of stand-scale modeling studies. Curr For Rep 1:53-68

Reyer C, Guericke M, Ibisch PL (2009) Climate change mitigation via afforestation, reforestation and deforestation avoidance: and what about adaptation to environmental change? New For 38:15-34

Reyer C, Bathgate S, Blennow K, Borges J, Bugmann H, Delzon S, Faias SP, Garcia-Gonzalo J, Gardiner B, Gonzalez-Olabarria JR, Gracia C, Hernández JG, Kellomäki S, Kramer K, Lexer MJ, Lindner M, van der Maaten E, Maroschek M, Muys B, Nicoll B, Palahi M, Palma JHN, Paulo JA, Peltola H, Pukkala T, Rammer W, Ray D, Sabaté S, Schelhaas M, Seidl R, Temperli C, Tomé M, Yousefpour R, Zimmermann NE, Hanewinkel M (2017) Are forest disturbances amplifying or canceling out climate changeinduced productivity changes in European forests? Environ Res Lett 12:034027. https://doi.org/10.1088/1748-9326/aa5ef1

Rodriguez-Franco C, Haan TJ (2015) Understanding climate change perceptions, attitudes, and needs of forest service resource managers. J Sust For 34:423-444

Rummukainen M (2012) Changes in climate and weather extremes in the 21st century. Wiley Interdisc Rev Clim Change 3:115-129 
Seidl R, Rammer W, Lexer MJ (2011) Adaptation options to reduce climate change vulnerability of sustainable forest management in the Austrian Alps. Can J For Res 41(4):694-706

Seidl R, Schelhaas M-J, Rammer W, Verkerk PJ (2014) Increasing forest disturbances in Europe and their impact on carbon storage. Nat Clim Change 4:930

Seidl R, Thom D, Kautz M, Martin-Benito D, Peltoniemi M, Vacchiano G, Wild J, Ascoli D, Petr M, Honkaniemi J, Lexer MJ, Trotsiuk V, Mairota P, Svoboda M, Fabrika M, Nagel TA, Reyer CPO (2017) Forest disturbances under climate change. Nat Clim Change 7:395-402

Sousa-Silva R, Ponette Q, Verheyen K, Van Herzele A, Muys B (2016) Adaptation of forest management to climate change as perceived by forest owners and managers in Belgium. For Ecosyst 3:22

Sousa-Silva R, Verbist B, Lomba Â, Valent P, Suškevičs M, Picard O, Hoogstra-Klein MA, Cosofret V-C, Bouriaud L, Ponette Q, Verheyen K, Muys B (2018) Adapting forest management to climate change in Europe: linking perceptions to adaptive responses. For Policy Econ 90:22-30

Stainforth DA, Allen MR, Tredger ER, Smith LA (2007) Confidence, uncertainty and decision-support relevance in climate predictions.
Philos Trans R Soc A Math Phys Eng Sci 365:2145-2161. https:// doi.org/10.1098/rsta.2007.2074

Sturrock RN, Frankel SJ, Brown AV, Hennon PE, Kliejunas JT, Lewis KJ, Worrall JJ, Woods AJ (2011) Climate change and forest diseases. Plant Pathol 60:133-149

Williams M, Dumroese K (2013) Preparing for climate change: forestry and assisted migration. J For 111:287-297

Williamson TB, Parkins JR, McFarlane BL (2005) Perceptions of climate change risk to forest ecosystems and forest-based communities. For Chron 81:710-716

Yousefpour R, Hanewinkel M (2015) Forestry professionals' perceptions of climate change, impacts and adaptation strategies for forests in south-west Germany. Clim Change 130:273-286. https:// doi.org/10.1007/s10584-015-1330-5

Publisher's Note Springer Nature remains neutral with regard to jurisdictional claims in published maps and institutional affiliations. 